DOI: 10.21005/pif.2021.47.C-05

\title{
SIGNIFICANCE OF THE TEHELNE POLÉ NATIONAL STADIUM FOR BRATISLAVA AND FOOTBALL DEVELOPMENT IN SLOVAKIA
}

ZNACZENIE STADIONU NARODOWEGO TEHELNÉ POLE DLA BRATYSŁAWY I ROZWOJU PIŁKI NOŻNEJ NA SŁOWACJI

\section{Szymon Usydus}

MSc. Arch.

Author's Orcid number: 0000-0002-6834-8869

Cracow University of Technology

Faculty of Architecture

City Rebuilding Laboratory

\section{ABSTRACT}

The Tehelné Pole football stadium in Bratislava is the largest and the most prestigious sports arena in Slovakia. In this paper the author characterises the specific features that distinguish this facility from other modern football stadiums. He analysed its significance to the popularisation of football in this country, using an original sports facility evaluation methodology. The author assessed the functioning of the stadium and distinguished the components influencing the effectiveness of its regionand state-wide operation, as well as on the district and city scale-in the macro and micro scales. The study demonstrates the development potential of the Slovak's football infrastructure compared to Central Europe.

Key words: football, stadium, Tehelné Pole, Bratislava, Slovakia.

\section{STRESZCZENIE}

Stadion piłkarski Tehelné Pole w Bratysławie to największa i zarazem najbardziej prestiżowa arena sportowa na Słowacji. Autor charakteryzuje jej specyficzne cechy wyróżniające ten obiekt od innych współczesnych stadionów piłkarskich. Analizuje jego znaczenie dla popularyzowania piłki nożnej w tym kraju posługując się przy tym autorską metodologią badania obiektu sportowego. Ocenia sposób funkcjonowania stadionu oraz wyróżnia elementy składowe wpływające na efektywność jego działania w skali regionu i kraju oraz miasta i dzielnicy - w skalach makro i mikro. W wyniku badań wykazuje potencjały rozwojowe infrastruktury piłkarskiej Słowacji na tle regionu Europy Środkowej.

Słowa kluczowe: piłka nożna, stadion, Tehelné Pole, Bratysława, Słowacja. 


\section{INTRODUCTION}

There are few places in the modern world where people are not passionate about football (Sourav, 2020). Nevertheless, such isolated oases where this discipline gives way to another, no less popular one do exist. According to the literature, one such unique place where ice hockey is the most popular sport is Slovakia (Wood, 2015). This phenomenon is justified by the long traditions of this sports discipline in the country, achieved at the level of the national team and local hockey clubs (HC BULLS, 2020). Slovakian achievements in football are not as impressive. However, the ease of practising this sport, compared to the requirements of hockey and its global dimension, signifies that both of these disciplines can now be compared almost equally in terms of popularity in Slovakia.

The most famous and successful sports club in Slovakia is Slovan Bratislava. After the dissolution of Czechoslovakia, this team won the national football championship nine times. The only team that can try to match this result is MŠK Žilina, which won the national league seven times. The most visible limitation that was holding back Slovan's development for years was its outdated stadium. The Tehelné Pole stadium, in the Nové Mesto district, has been the heart of Bratislava's recreation and sports zone since its opening in 1941. This multi-section club deserves recognition, as its facilities include not only a football team but also hockey, rugby, basketball and many other sports sections. They are scattered in various places around the football stadium, as there is no room for them in this complex.

The original Tehelné Pole stadium was demolished in 2013 to build a new one in its place. This process began three years later, and the ceremonial inauguration of the new facility took place on 3 March 2019. The National Stadium in Bratislava was one of many sports facilities to be built in Slovakia in the last decade. During this period, many leading clubs in the country modernised their stadiums or built them from scratch. This took place in, among other places, Poprad (2014), Trnava (2015), Dunajská Streda (2017) and Nitra (2018). Another football arena will soon be built in Trenčin.

One of the reasons for the construction of the new stadium in Bratislava was the fact that the old Tehelné Pole stadium ceased to meet the requirements of international football federations for the organisation of national team matches. For the city authorities, it was a kind of affront that forced the decision to build a new stadium. The new Tehelné Pole, designed by Karol Kallay (the author of, among others, the Slovak Pavilion at EXPO 2015 in Milan), aspired to be the national football stadium from the beginning - it was intended to be the largest and most prestigious sports arena in the country. In an interview, the architects revealed that for this purpose, from the very beginning, they had to design the facility following stringent UEFA guidelines, to get the highest, four-star rating (Kallay ml., 2020). Among the regulations the designers took into account were all the quality standards ensuring the highest comfort for viewers, media representatives and athletes (UEFA, 2018). Ultimately, the facility successfully passed a UEFA inspection and easily obtained the necessary quality certificate (TASR, 2020).

To evaluate the quality of this project and gain insight into its impact on the development of Bratislava, a large city in Central Europe, the author made an attempt to comprehensively evaluate the functioning of the stadium and distinguish the components that influence the effectiveness of its operation across various scales: the region, the city and the district. The full case study analysis is complemented by qualitative studies, such as statistical comparisons, as well as information obtained from interviews with experts in the field of sports architecture.

Research carried out using these methods enabled the verification of plans and explain concepts (the design tools used and processes that take place in the space) concerning the place's characteristics, considered in various contexts: social, cultural, historical, ecological, economic and security.

\section{REGIONAL SCALE}

Slovakia has never been a powerhouse of European football-this is evidenced by several rankings both for national teams (FIFA ranking, as of 22 October 2020: thirty-seventh place in the world, twenty-first place in Europe) and league teams (twenty-ninth UEFA factor). However, the country has the potential to play a greater role on the European market. The examples of Austria and the Czech 
Republic clearly shows that even countries comparable in terms of population to Slovakia can have a strong national team and football league.

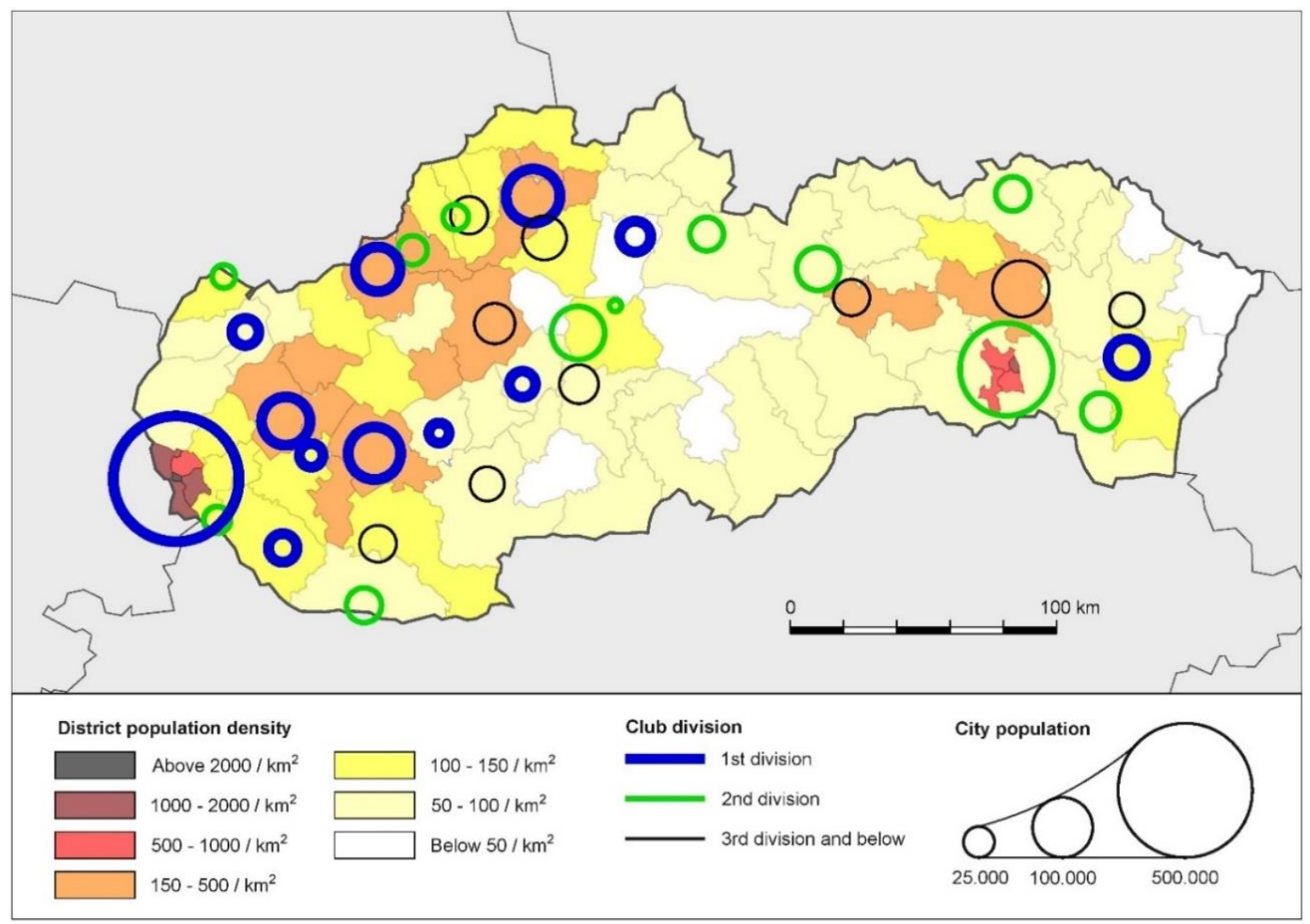

Fig. 1. Map showing the distribution and fan potential of football clubs in Slovakia. Source: original work Ryc. 1. Mapa obrazująca rozkład i potencjał kibicowski klubów piłkarskich na Słowacji. Źródło: ilustracja autora

One of the factors that slow down the development of sports in Slovakia is the shape of the country's border and the unusual location of its capital-which is adjacent to the western border. Due to this fact, the centre of gravity to the country's population density is tilted towards the west. The east of the country is much less dense. The clubs from this area play a marginal role in the national league structure. Only the team from Michalovec is in the highest division, while teams from Košice, Bardejov and Trebišov play in the second tier (Fig. 1).

The concentration of strong clubs in the west of Slovakia means that even though Slovan Bratislava is the most popular football club in the country, it has limited opportunities to attrat fans from other regions. This is evidenced by the list of five cities with football clubs in the highest domestic league within $100 \mathrm{~km}$ from Bratislava: Senica $(25 \mathrm{~km})$, Dunajská Streda $(45 \mathrm{~km})$, Trnava $(48 \mathrm{~km})$, Sered' $(55 \mathrm{~km})$ and Nitra $(88 \mathrm{~km})$.

Another factor that certainly does not facilitate the popularisation of football in Bratislava is the proximity of the city of Vienna. The Austrian league is at a much higher level than the Slovak one, and this according to experts certainly makes fans who rate the level of football games above local patriotism decide to watch the Austrian Bundesliga (Kuper and Szymański, 2017). Vienna is represented in this league by three teams: Austria, Rapid and Admira Wacker. 
Tab 1. Average attendances, stadium capacities and the population of Slovak cities with football clubs in highest division (Fortuna Liga) in the 2018/19 season. Source: transfermarkt.de

\begin{tabular}{|l|r|r|r|}
\hline City & Population & St. cap. & Av. Att. \\
\hline Bratislava & 432.864 & 22.500 & 6.114 \\
\hline Žilina & 82.954 & 11.313 & 2.577 \\
\hline Nitra & 76.655 & 11.384 & 1.086 \\
\hline Trnava & 63.924 & 19.200 & 3.700 \\
\hline Trenčin & 55.333 & 4.300 & 564 \\
\hline Michalovce & 30.950 & 7.000 & 1.437 \\
\hline Ružomberok & 26.709 & 5.000 & 1.372 \\
\hline Dunajská Streda & 22.730 & 12.700 & 7.996 \\
\hline Senica & 20.324 & 5.070 & 906 \\
\hline Žiar nad Hronom & 19.083 & 2.309 & 1.546 \\
\hline Zlaté Moravce & 11.465 & 4.000 & 2.466 \\
\hline
\end{tabular}

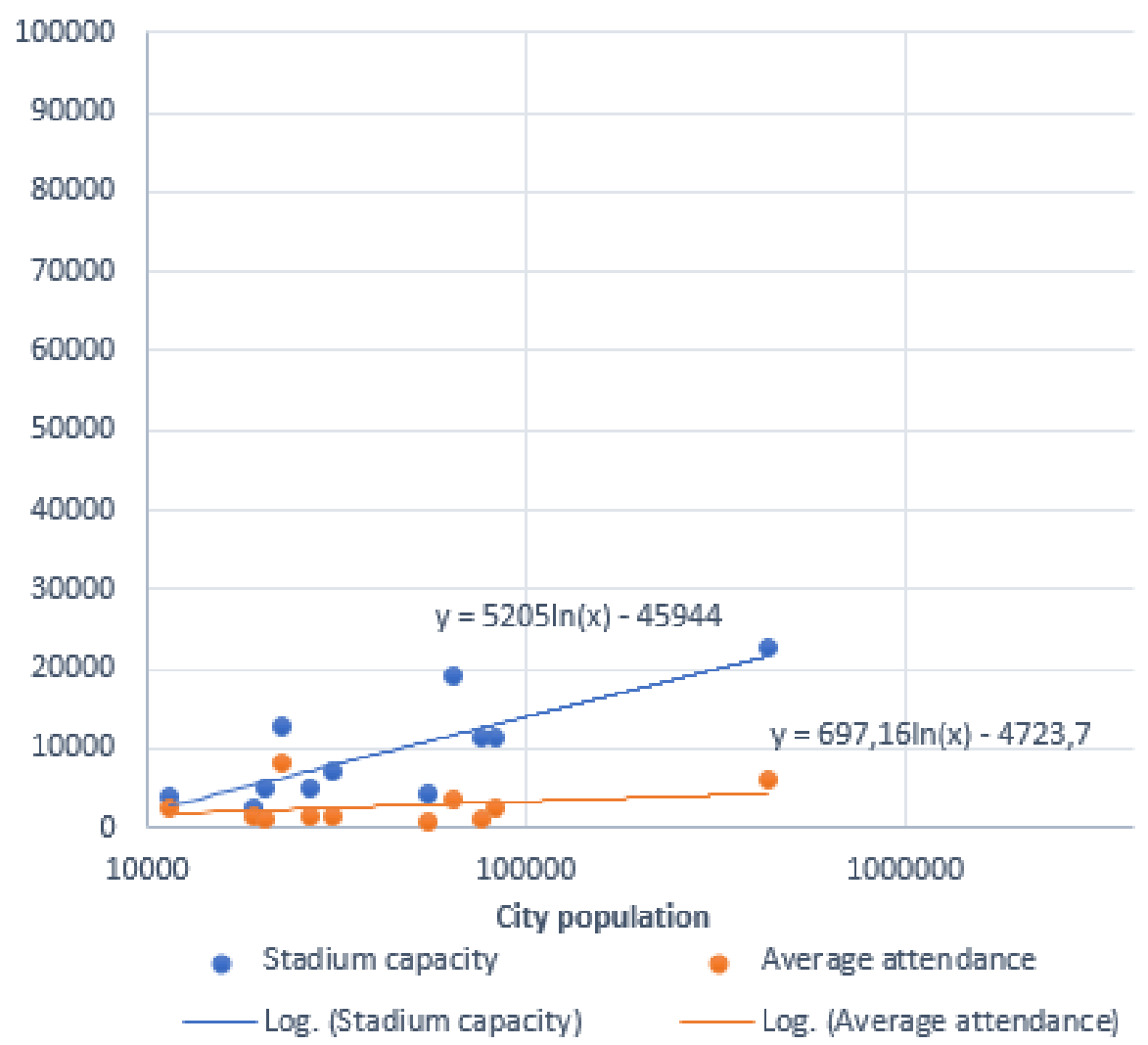

Fig. 2. A comparison of the trend lines of the average capacity of football club stadiums in Slovakia and their average attendance in the $2019 / 20$ season and the city's population. Source: original work

Ryc. 2. Zestawienie linii trendów średniej pojemności stadionów klubów piłkarskich na Słowacji i ich średnich frekwencji w sezonie 2019/20 w stosunku do liczby mieszkańców miasta. Żródło: ilustracja autora 
Tab 2. Average attendances, stadium capacities and the population of Polish cities with football clubs in highest division (Ekstraklasa) in the 2018/19 season. In the case of Krakow both stadiums' capacities and their average attendances were summed. Source: transfermarkt.de

\begin{tabular}{|l|r|r|r|}
\hline City & Population & St. cap. & Av. Att. \\
\hline Warsaw & $1,777,972$ & 30,967 & 18,672 \\
\hline Krakow & 771,069 & 48,146 & 25,166 \\
\hline Łódź & 685,285 & 5,700 & 5,295 \\
\hline Wrocław & 640,648 & 42,771 & 14,613 \\
\hline Poznań & 536,438 & 42,834 & 14,941 \\
\hline Gdańsk & 466,631 & 43,615 & 10,703 \\
\hline Szczecin & 402,465 & 18,027 & 3,699 \\
\hline Częstochowa & 222,292 & 5,648 & 2,950 \\
\hline Kielce & 195,774 & 15,500 & 7,037 \\
\hline Gliwice & 179,806 & 10,037 & 4,494 \\
\hline Zabrze & 173,374 & 24,563 & 13,167 \\
\hline Płock & 120,000 & 10,978 & 4,522 \\
\hline Lubin & 72,581 & 16,086 & 4,116 \\
\hline
\end{tabular}

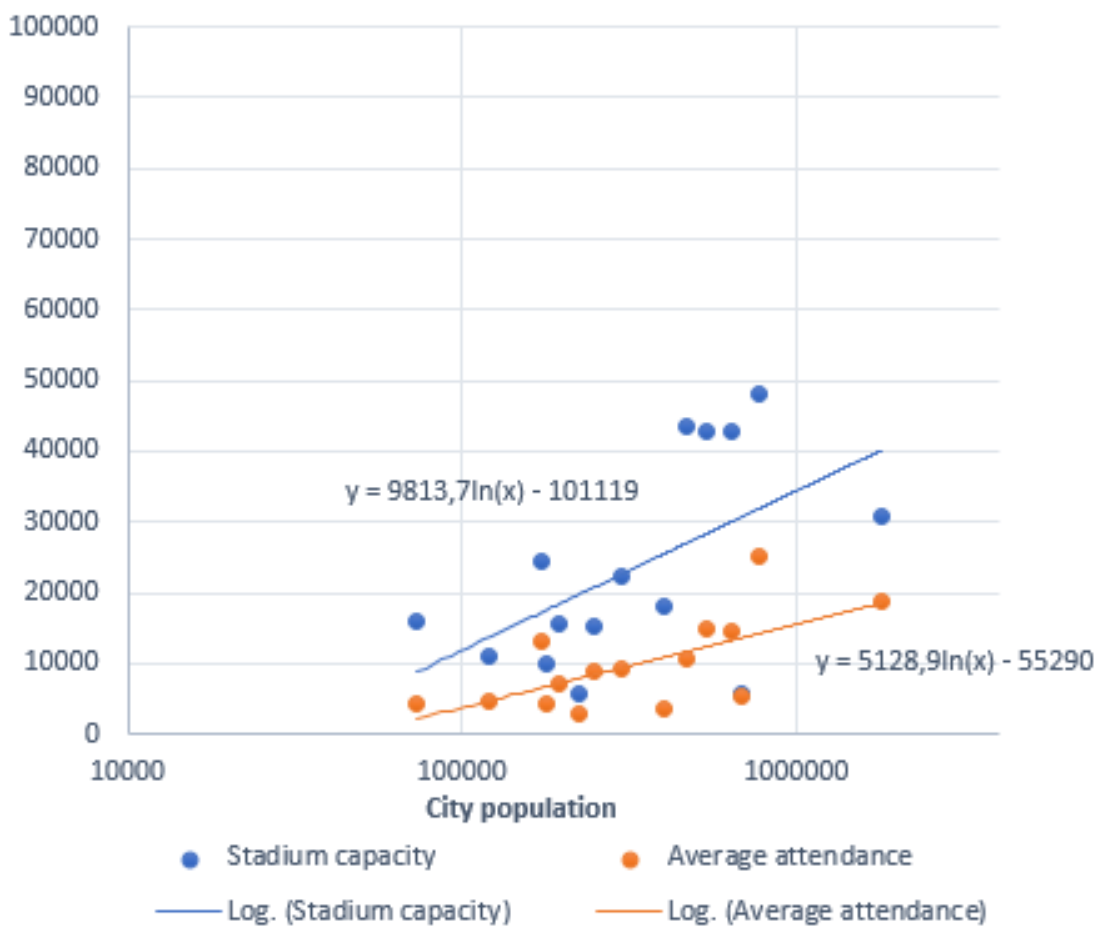

Fig. 3. A comparison of the trend lines of the average capacity of football club stadiums in Poland and their average attendance in the 2019/20 season and the city's population. Source: original work

Ryc. 3. Zestawienie linii trendów średniej pojemności stadionów klubów piłkarskich w Polsce i ich średnich frekwencji w sezonie 2019/20 w stosunku do liczby mieszkańców miasta. Żródło: ilustracja autora 
Tab 3. Average attendances, stadium capacities and the population of German cities with football clubs in highest division (Bundesliga) in the $2018 / 19$ season. In the case of Berlin both stadiums' capacities and their average attendances were summed. Source: transfermarkt.de

\begin{tabular}{|l|r|r|r|}
\hline City & Population & St. cap. & Av. Att. \\
\hline Berlin & $3,644,826$ & 96,661 & 71,147 \\
\hline Munich & $1,471,508$ & 75,024 & 75,000 \\
\hline Cologne & $1,085,664$ & 50,000 & 49,717 \\
\hline Frankfurt & 753,056 & 51,500 & 50,020 \\
\hline Dusseldorf & 619,294 & 54,600 & 41,324 \\
\hline Leipzig & 587,857 & 42,146 & 40,809 \\
\hline Dortmund & 587,010 & 81,365 & 81,171 \\
\hline Bremen & 569,352 & 42,100 & 40,821 \\
\hline Augsburg & 295,135 & 30,660 & 28,710 \\
\hline Mönchengladbach & 261,454 & 54,022 & 51,103 \\
\hline Gelsenkirchen & 260,305 & 62,271 & 61,075 \\
\hline Freiburg & 230,241 & 24,000 & 23,925 \\
\hline Mainz & 217,118 & 34,000 & 27,081 \\
\hline Leverkusen & 163,838 & 30,210 & 27,770 \\
\hline Paderborn & 150,580 & 15,000 & 14,434 \\
\hline Wolfsburg & 124,151 & 30,000 & 24,351 \\
\hline Hoffenheim & 35,442 & 30,150 & 26.741 \\
\hline
\end{tabular}

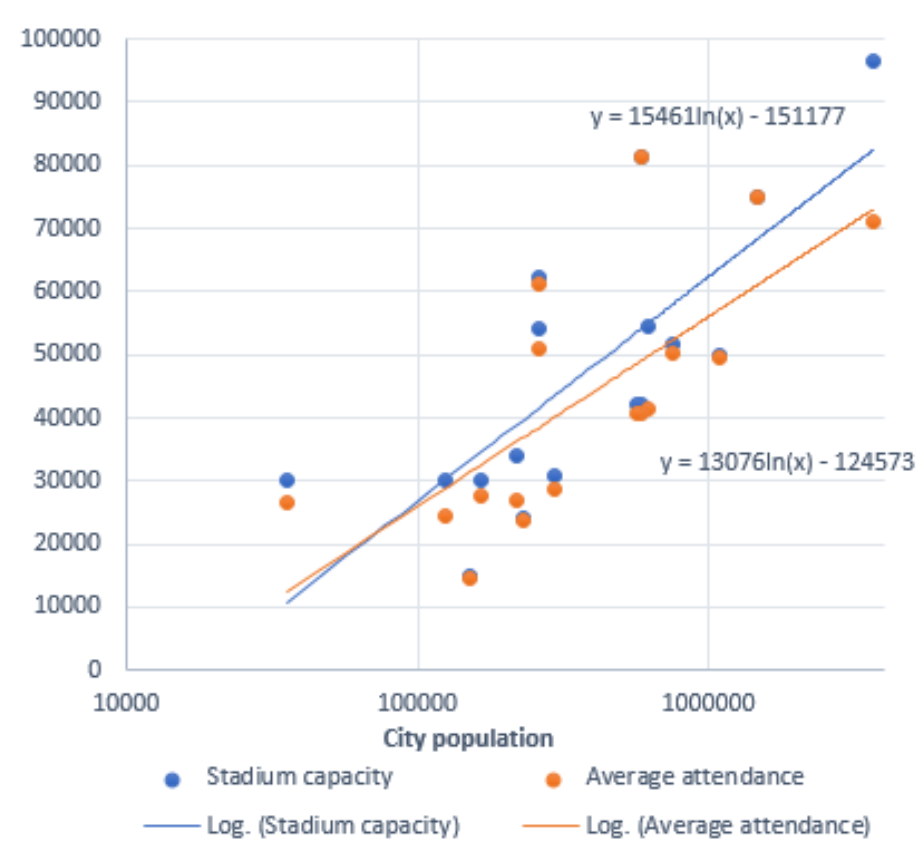

Fig. 4. A comparison of the trend lines of the average capacity of football club stadiums in Germany and their average attendance in the 2019/20 season and the city's population. Source: original work

Ryc. 4. Zestawienie linii trendów średniej pojemności stadionów klubów piłkarskich w Niemczech i ich średnich frekwencji w sezonie 2019/20 w stosunku do liczby mieszkańców miasta. Źródło: ilustracja autora 
To visualise the football fans' potential and the infrastructure of the Slovak league against other countries, charts were developed showing trend lines for stadium capacity (blue function) and average attendance (orange function) relative to the population of a specificity (X-axis) for three countries: Slovakia, Poland and Germany. Such a comparison makes it possible to reflect the infrastructural differences between Slovakia and the other two countries of the same region (Central Europe), which have a more developed sports infrastructure and observe a greater interest in watching sports events live.

The charts show that the demand for sports infrastructure in Slovakia (Fig. 2) is much lower than in Poland (Fig. 3) and Germany (Fig. 4). This tendency is visible when comparing the angles of inclination of both functions. In the case of Germany, they were growing the fastest. Moreover, their outlines reflect actual demand for viewing football matches live in a given country. The degree of interest in viewership highlights the overlap between these two functions. Their comparison shows that for Slovakia, they come into contact with each other at the origin point, and then begin to deviate from each other (average attendance: $32 \%$ ). On the other hand, the functions on the graph for Poland are nearly parallel. However, they are far apart (average attendance: $45 \%$ ). The model example of Germany shows the greatest degree of function similarity (average attendance: $92 \%$ ).

The average stadium capacity in this country was found to be equal to $16.2 \%$ of the city's population, with values for Poland and Slovakia being $7.5 \%$ and $21.9 \%$, respectively. However, the average attendance relative to the city's population in these countries was $14.7 \%, 3.0 \%$ and $8.3 \%$ (Tab. 1-3). This data shows that Slovak clubs have stadiums with capacity reserves that exceed their needs (Fig. 2-4).

\section{CITY SCALE}

Slovan Bratislava's dominance in terms of popularity is even more evident on the city scale. This club is considered a monopolist in the capital city because it is the only team there that has been playing in the first division since the 2010/11 season. This gives the club the highest supporters attraction potential in Slovakia. Until the 2009/10 season, FC Petržalka (now in the second league) also played in the first Slovak league, with financial support from famous businessman Ivan Kmotrik. This period saw the club dominate the league and the team's greatest successes: winning two national championships (2004/05 and 2007/08 season) and a promotion to the group stage of the UEFA Champions League - the most prestigious club tournament in football in the world (2005/06). Without a sponsor, the team's prosperity ended. Due to financial problems, the club was forced to send away its best players. According to Broda, this was the ultimate factor that made it lost its place in the first league and has not returned to it to this day (Broda, 2019). In addition to Petržalka, the country's capital has also had other illustrations football representatives. Few traces of these clubs remain today-they have either been dissolved or are a shadow of the former selves. One of such examples is Inter Bratislava-two-times champions of Slovakia during the 1999/00 and 2000/01 seasonswhich now plays at the third level of the competition (Tab. 4).

Table 4. List of active football teams in Bratislava in the 2020/21 season, the division in which they play, the year they were established and the distance of their stadium/pitch from Tehelné Pole stadium. Source: original work

\begin{tabular}{|l|c|c|r|}
\hline Club name & $\begin{array}{c}\text { Division } \\
(\mathbf{2 0 / 2 1 )}\end{array}$ & $\begin{array}{c}\text { Year } \\
\text { of est. }\end{array}$ & $\begin{array}{c}\text { Distance } \\
\text { to T.P. } \\
\text { [km] }\end{array}$ \\
\hline Slovan Bratislava & 1 & 1919 & n.d. \\
\hline FC Petržalka & 2 & 1898 & 5.8 \\
\hline Inter Bratislava & 3 & 1940 & 1.4 \\
\hline Rača Bratislava & 3 & 1925 & 5.5 \\
\hline Lokomotíva Devínska Nová Ves & 3 & 1923 & 15.3 \\
\hline ŠK Vrakuňa Bratislava & 4 & 1939 & 6.4 \\
\hline
\end{tabular}




\begin{tabular}{|l|c|c|r|}
\hline Club name & $\begin{array}{c}\text { Division } \\
(\mathbf{2 0 / 2 1 )}\end{array}$ & $\begin{array}{c}\text { Year } \\
\text { of est. }\end{array}$ & $\begin{array}{c}\text { Distance } \\
\text { to T.P. } \\
\text { [km] }\end{array}$ \\
\hline FKM Karlova Ves Bratislava & 4 & n.d. & 7.1 \\
\hline SDM Domino & 4 & 1993 & 2.6 \\
\hline FK Vajnory & 4 & 1933 & 9.0 \\
\hline FK Lamač Bratislava & 4 & 1943 & 10.2 \\
\hline TJ Jarovce Bratislava & 5 & 1949 & 12.9 \\
\hline NŠK 1922 Bratislava & 5 & 1922 & 1.6 \\
\hline MŠK Iskra Petržalka & 5 & 1934 & 8.4 \\
\hline ŠK Krasňany Bratislava & 5 & n.d. & 4.9 \\
\hline MKF Slovan Záhorská Bystrica & 5 & n.d. & 14.6 \\
\hline FK The Dragons & 6 & 2011 & 0.9 \\
\hline Futbalová Komunita Kozmos & 6 & 2019 & 2.0 \\
\hline FTJ Slávia Ekonóm Bratislava & 6 & 1955 & 0.5 \\
\hline
\end{tabular}

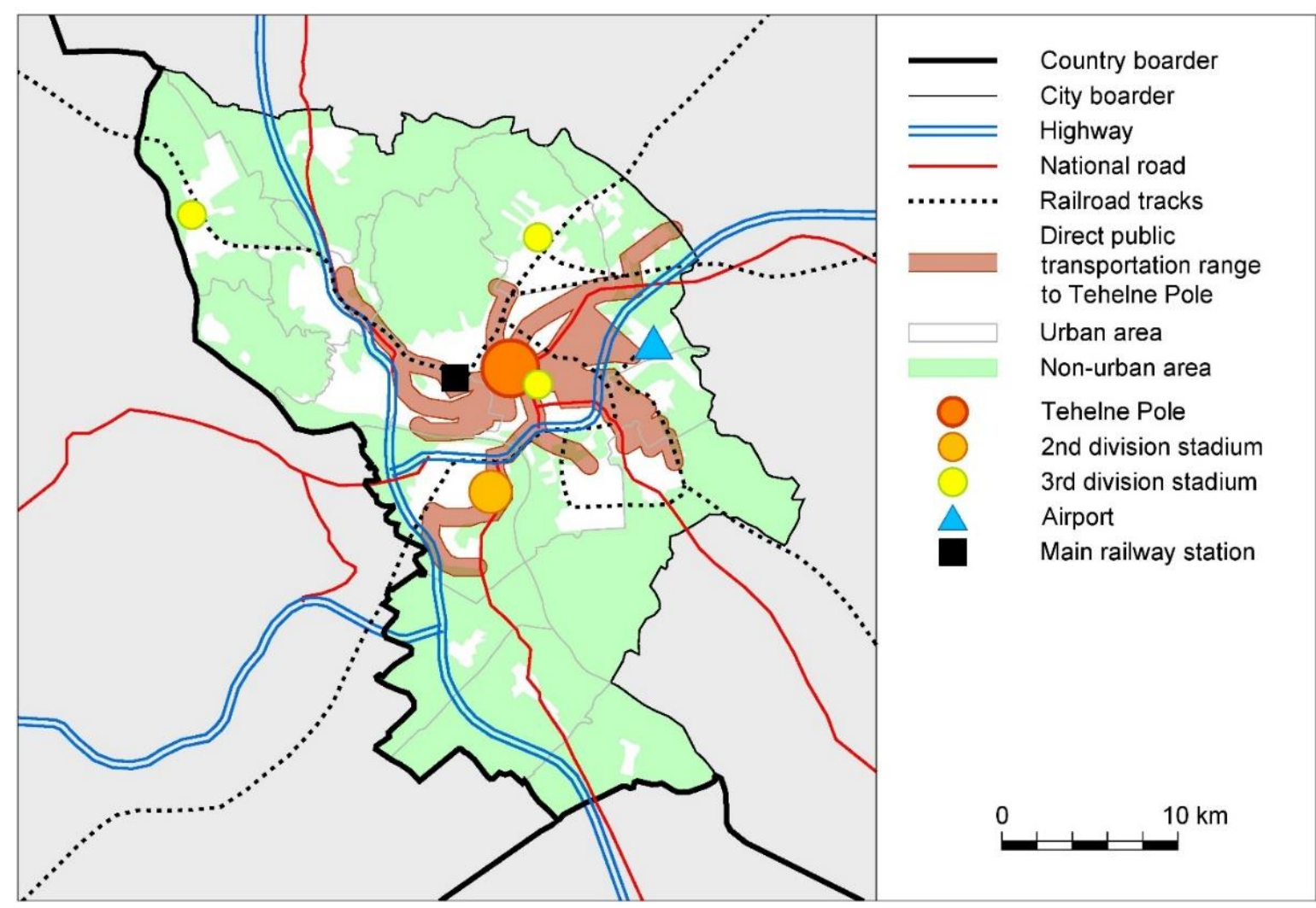

Fig. 5. City-scale analysis of the Tehelné Pole stadium location. Source: original work Ryc. 5. Analiza lokalizacji stadionu Tehelné Pole w skali miasta. Źródło: ilustracja autora

The location of the Tehelné Pole stadium is ideal in terms of accessibility to the city's inhabitants. Its site is located in the central part of the Nové Mesto district-the new commercial centre of Bratislava. 
The stadium is situated close to the public transport stops $(200 \mathrm{~m})$, which allow ease of accessibility-arrival by bus or tram from almost all parts of the city. Close proximity to a railway stop $(1,5 \mathrm{~km})$ and an airport $(5,3 \mathrm{~km})$ is beneficial to visitors from further parts of the country and foreign supporters (Fig. 5).

\section{DISTRICT SCALE}

Until the twentieth century, the Nové Mesto district, where Tehelne Pole is located, was a poorly urbanised area on the northern outskirts of Bratislava. The first more important buildings began to be built there only in the 1920s. These were industrial plants, which included a brewery, dynamite and chocolate factories. The development of the district changed its direction after the occupation of Petržalka, located in the south of the city, by Nazi Germany (1938) and access restrictions placed on residents. At that time, the most important recreational and sports facilities of the city were located there. According to Fischer, Bratislava's authorities decided to compensate for this shortage by building new sports arenas in the Nové Mesto district (Fischer, 2020).

Within it, successive sports facilities were built: an athletics and football stadium, a speedway track, a winter stadium, a municipal swimming pool, a bicycle stadium and tennis courts. The first to be built was a football and athletics stadium designed by Kamil Gross. The facility for 25,000 spectators, with 1,750 seats, was put into operation on 26 September 1940. After the war, the stadium's capacity was gradually increased, reaching the maximum number of seats for 60,000 spectators. In the 1990 s, the stadium underwent its last modernisation, which resulted, among others, in the reduction of the facility's capacity to 30,000 seats. The stadium was finally demolished in 2013 and a completely new facility was designed in its place (Kováč, 2014).

Today, the recreation, sports and commercial complex is the modern centre of the Slovak capital, and the Tehelné Pole National Stadium, built in 2019, is considered its "heart" (Fig. 6). Previously, its current role was played by two stadiums: the old Tehelné Pole and Pasienky - the former stadium of Inter Bratislava. The facility is still used by Slovan Bratislava. It hosts, among others, the matches of this club's reserve team. Its characteristic tall lighting columns are spatial landmarks even today, thanks to which the location of the stadium is easier to find than that of Tehelné Pole. Without prior knowledge about its location, it is much more difficult to locate it. This impression has been intensified by the construction of successive high-rise buildings built in the district. The characteristic Tri Veže complex, designed by Peter Moravčík, is located right next to Tehené Pole, are the most recognisable element that guides towards the stadium.

The present-day recreational and sports complex also includes a swimming pool, tennis courts (two groups), football fields, ice hockey stadium, sports hall, Jama Park, the Kuchajda reservoir and a multi-arena. In this zone, there are also smaller recreational spaces and sports facilities that house clubs which attract smaller groups of the sports community. The complex also includes commercial facilities, including a Kaufland store and the Polus shopping centre. Thanks to these functions, supporters may go shopping before or after a mass event, extending the duration of their stay in the district. This activity is also encouraged by the presence of significant circulatory arteries throughout this area. They connect the district to the rest of the city and its exit roads, improving the zone's accessibility. However, at the same time, it loses its functional qualities to supporters travelling on foot. The intense car traffic may increase the risk of accidents.

\section{STADIUM SCALE}

The Tehelné Pole stadium was completed in February 2019 and had its official opening on the 3 March 2019, the day of the prestigious Slovan Bratislava-Spartak Trnava match. On that day, for the first time, the facade of the stadium, which consists of illuminated membranes, changed its hues to the club's colours (blue) (Fig. 7). Illumination effects are also used during matches of the national team. According to Kallay's knowledge, the hue of the facade glows with the colours of the Slovak flag on such occasions (Kallay ml., 2020). 


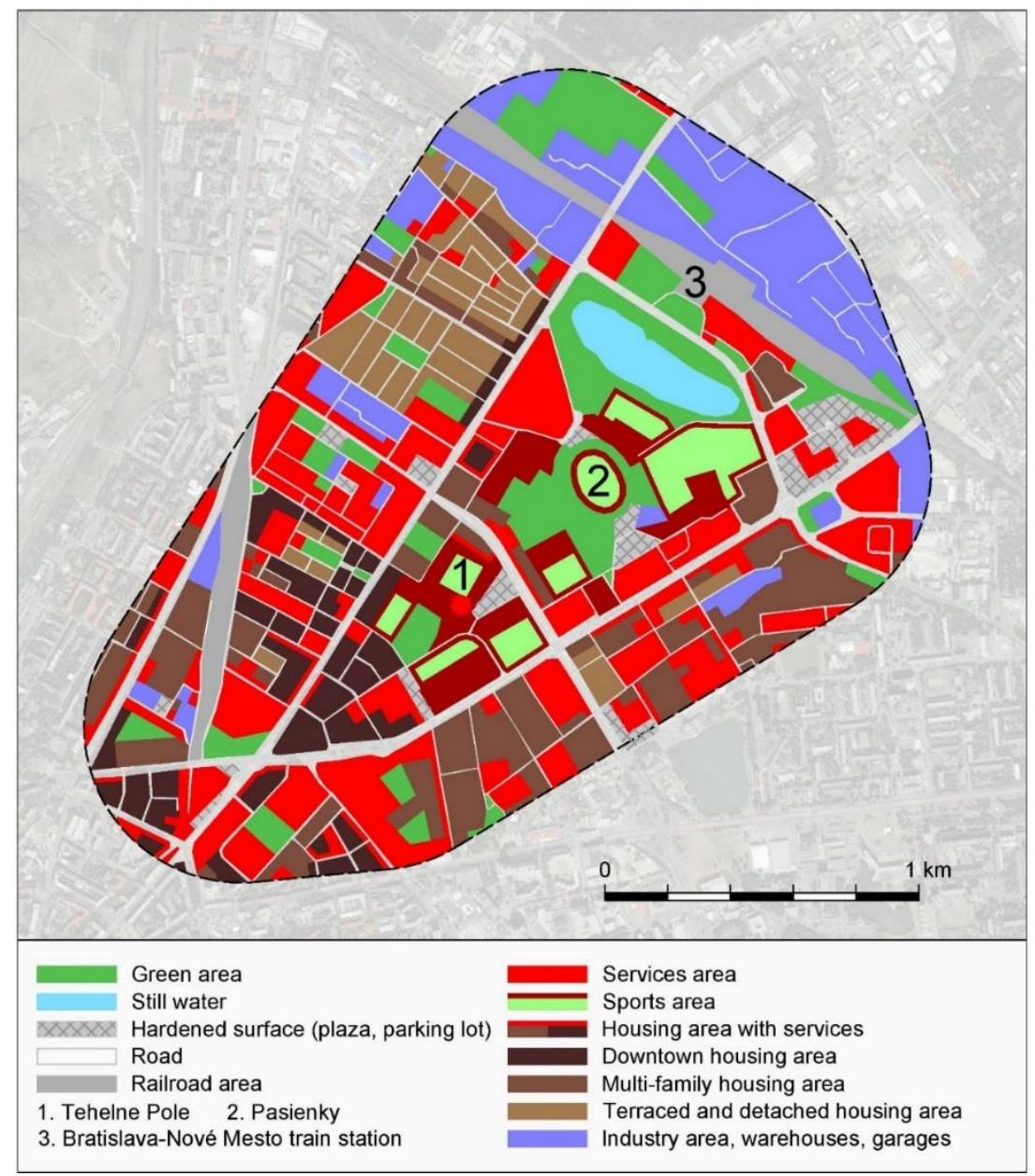

Fig. 6. District-scale analysis of the Tehelné Pole stadium's location. Source: original work Ryc. 6. Analiza lokalizacji stadionu Tehelné Pole w skali dzielnicy. Źródło: ilustracja autora

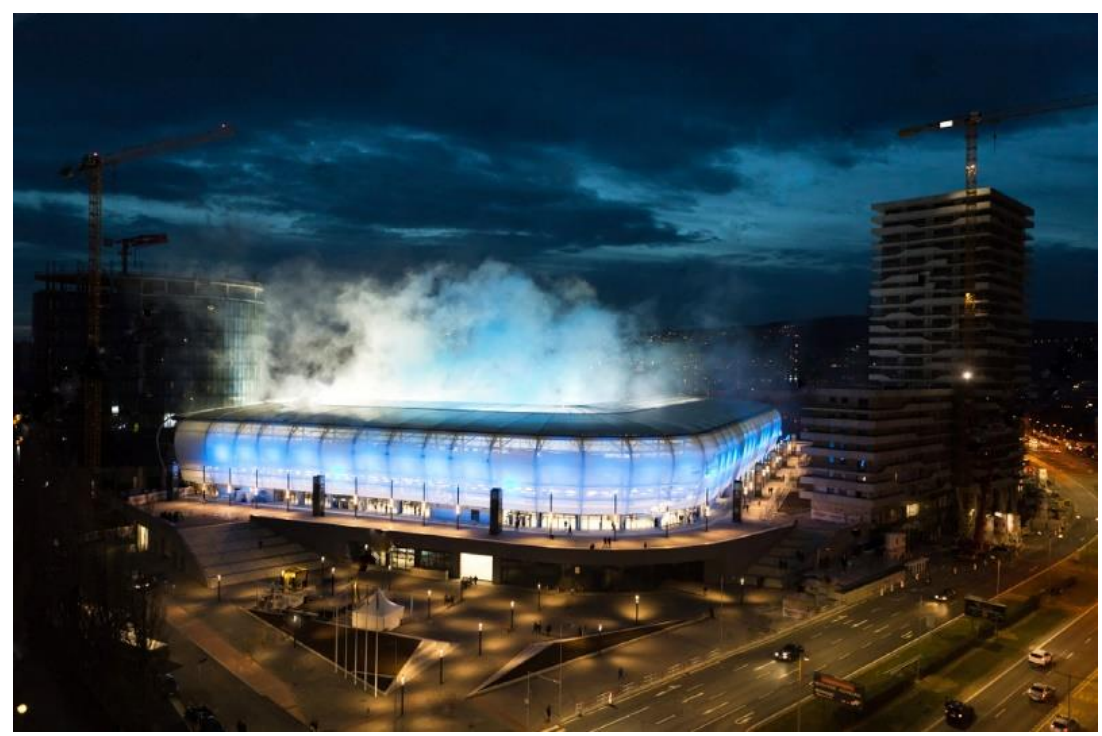

Fig. 7. Tehelné Pole, 03.03.2019. Source: Marek Valovic, shutterstock.com, ID: 1329322736

Ryc. 7. Tehelné Pole, 03.03.2019. Źródło: Marek Valovic, shutterstock.com, ID: 1329322736 
One of the characteristic elements that distinguish Tehelné Pole from other modern stadiums is an office building built in the corner of the arena. According to Zinganel's theory, this was necessary due to the guidelines of the city's authorities, who, to ensure the financial success of the project, sought to diversify its functions (Zinganel, 2010). Besides, the land development plan assumed the construction of multi-family residential buildings from the side of Bajkalskà Street. Such actions caused that these facilities had to be integrated into the structure of the stadium. The residential building, despite being completed, is still not fully inhabited. This also applies to service spaces located on the ground level of the facility. Their arrangement requires appropriate adjustment in such a way that it is possible to reconcile the daily reception of customers (except of match days) with the supporters' service during the match days and other mass events. On such time, the quantity and range of their needs (purchases made) is highly demanding of the sellers, which according to experts they are not always able to meet (Usydus, 2020).

Several public spaces have been designed around the stadium, favouring the integration of residents and supporters. Currently, due to the threat posed by the COVID-19 pandemic, they are almost completely depopulated and do not resemble the living spaces around sports arenas. At Tehelné Pole, the spaces in front of the stadium's entrance stand out in the form of a terrace that surrounds the facility, elevated six metres above street level. Ramps and stairs lead to it and also serve as a form of security measure. The designers took into account the needs of the elderly and the disabled, for whom all kinds of ramps and stairs are a considerable difficulty, and placed special lifts for them inside the stadium structure.

The facade is designed in the form of a gallery that enables walking around the facility and reaching the appropriate zone, as shown on the purchased ticket. Most of the space has been adapted to mass movement, but it seems that some are too narrow and thus unsuitable for it. Theoretically, there should be no problems in the event of an evacuation, because according to simulations, emptying the stadium during an emergency takes a total of six minutes (Kallay ml., 2020). The arrangement of the sound system has a high impact on the improvement of safety in the facility. It is evenly distributed inside and outside the building. Thanks to this procedure, regardless of the fans' location, audio messages should be perfectly audible.

Tickets for sports events can be bought at two stationary sales points, located on opposite sides of the stadium, and online. After presenting the ticket, each supporter is photographed. Club authorities assure, that the captured images of the participants are a significant element of the security system (ŠK Slovan Bratislava, 2019). Among the security features, the transparent mesh surrounding the arena allows a good view of its interior and what is happening inside the facility. Stadium managers also praise the innovative method of making cashless purchases at the stadium. Eisele says, that for the duration of a mass event, supporters/viewers can purchase vouchers and then exchange them for products (food and drinks, souvenirs) offered during the event (Eisele, 2020).

Special underground parking zones have been designed under the facility, assigned to each function of the stadium structure. Once the car has been parked, lifts provide access to each building. The exit from the underground car park is aided by the use of exit ramps leading directly onto the main road. Thanks to this solution, it was not necessary to provide large parking spaces for cars and coaches around the facility. Drivers who, for various reasons, do not want to enter the underground car park, may leave their cars at street parking lots adjacent to the stadium.

The capacity of the Tehelné Pole stadium is a matter of debate. This has been already been discussed in the paper, pointing to the overestimated capacity of stadiums in Slovakia. Taking into account Slovan Bratislava, which had an average attendance close to the league's average until the construction of the new stadium, this means that for a city with more than five times more inhabitants than the next largest city-Žilina, this is a poor result. The average attendances recorded prove that their value after the 2012/13 season was even lower than the league's average (Fig. 8). If we take the coefficient for Germany from the trend line of average stadium capacity in this country (Fig. 2), instead of a 22.500-seat stadium, Bratislava should build an arena for 50.000 spectators and fill it (with an average of 45.000 people). In the case of the coefficient for Poland (Figure 3 ), these numbers would be 26.000 seats, with an average occupancy of 11.200. This is theoretical speculation, but in reality the move of Slovan Bratislava to the new Tehelné Pole stadium brought a noticeable increase 
in average attendance from 3.382 to 6.114 . These numerical values, when compared with Gdańsk and Bremen / Augsburg (cities comparable in size to Bratislava) (Tab. 1-3) significantly deviate from the norm. Their growth by $81 \%$ is higher than the values given by Kościółek $(72 \%)$, for the so-called "New stadium effect" (Kościółek, 2014), but not impressive (average) compared to other clubs located in the capitals of Central European countries (Fig. 9).

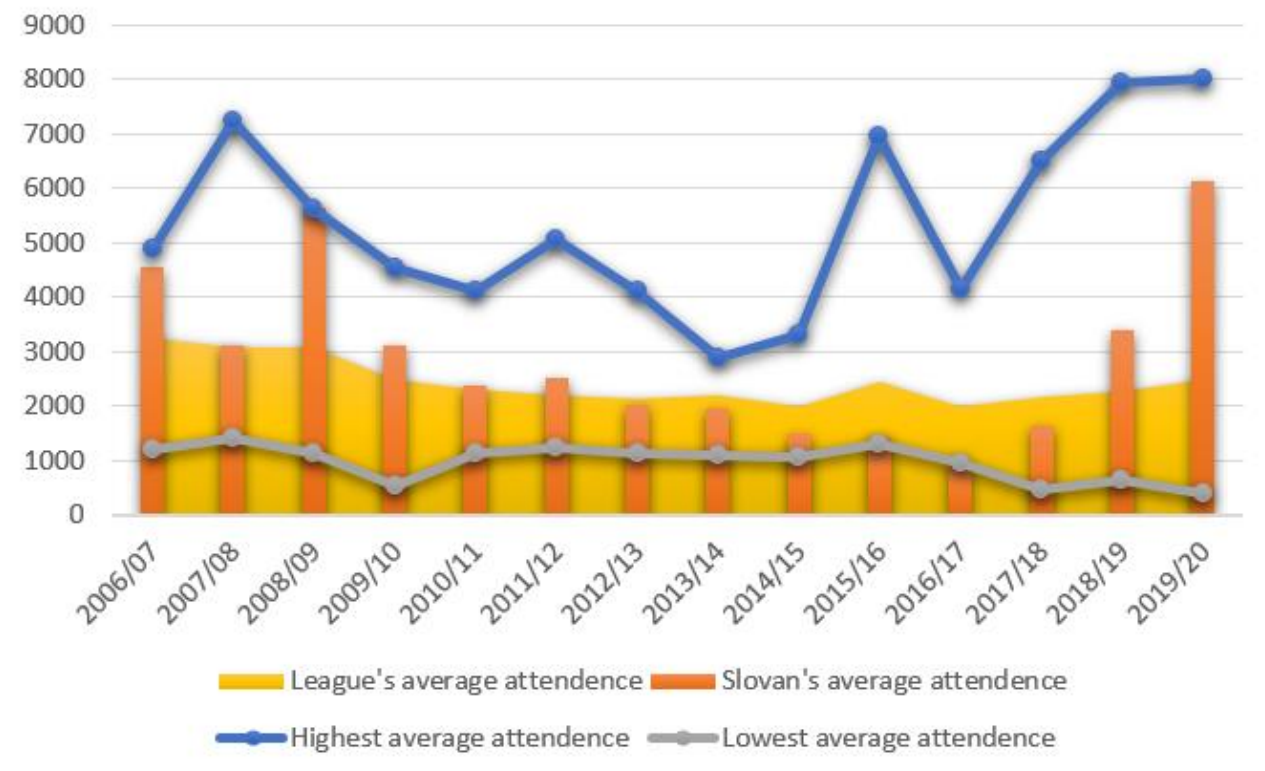

Fig. 8. Average Slovan Bratislava match attendance compared with the highest, average and lowest average attendance in the league between 2006/07 and 2019/20 seasons. Source: original work

Ryc. 8. Średnia frekwencja na meczach Slovana Bratysława w zestawieniu z najwyższą, średnią i najniższą średnią frekwencją w lidze w sezonach od 2006/07 do 2019/20. Źródło: ilustracja autora

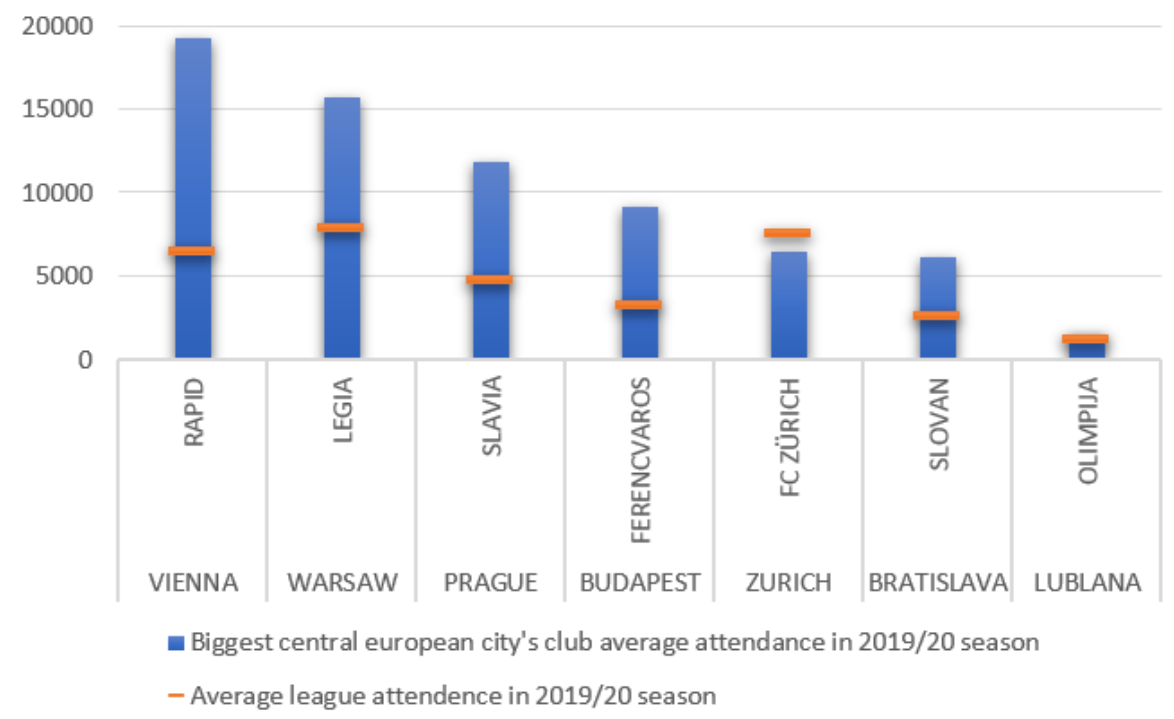

Fig. 9. Comparison of the average attendance of football clubs from the largest cities in Central Europe (excluding Germany) to the average league attendance of the highest division in these countries. Source: original work

Ryc. 9. Zestawienie średnich frekwencji klubów piłkarskich z największych miast krajów Europy Środkowej (z pominięciem Niemiec) w stosunku do średnich ligowych frekwencji najwyższych klas rozgrywkowych w tych krajach. Żródło: ilustracja autora 
The attendance deficit in Slovak stadiums was deepened by restrictive regulations (restrictions) related to the COVID-19 pandemic. The country's authorities were cautiously limiting the number of supporters attending the stadiums during league matches. Additionally, the owners of the facilities had to take care of the safety of supporters and adapt the stadiums to sanitary requirements. The fulfilment of these conditions consisted of marking the seats that could be taken and placing devices for disinfecting hands around the facility. Along with the growing number of daily new infection cases, on 1 November 2020, a decision was made to completely close all stadiums to supporters. Since then, football matches have been held without the public's participation, as in most European countries. This regulation was changed at the beginning of the 2021/22 season. From July 2021, fans of Slovak clubs can fill stadiums up to $50 \%$ of their capacity for the duration of football matches. Despite this, the attendance metrics collected so far (as of 18 August 2021) do not indicate that any club will come closer to this limit.

\section{CONCLUSIONS}

This study unquestionably shows Bratislava's immense potential for sports infrastructure development, which is unmatched by other Slovak cities. However, it cannot be argued that projects in this area, in this city, should be a model and inspiration for newly planned sports facilities in the country. The example of relocating the Tehelné Pole National Stadium shows that it was a key decision that started the city's development towards the north in the following decades. The stadium, along with the recreational and sports infrastructure that was successively developed around it, was the main factor for which new modern buildings of various functions (service, residential) and supporting infrastructure were built in this district. Over time, all these actions began to gradually raise the district's rank, and the constant construction of new buildings proves that this trend will continue in the coming years.

The opening of Tehelné Pole was intended not only to accelerate the development of the Nové Mesto district but also to start a new chapter in the history of Slovan Bratislava and Slovak football. However, the decision to close stadiums to Slovak supporters stopped the club's promising development for an indefinite time. It is believed that with the return to usual playing conditions, Slovan Bratislava should rapidly improve its financial performance. Experts agree that changing the facility from monofunctional to multifunctional, by extending its functions, will bring results and the investment will pay for itself regardless of the organisation of football matches (Palvarini and Tosi, 2013). A large number of service spaces, multifunctional halls inside the facility, but most importantly the possibility of hosting other mass events on the central pitch, will cause Tehelné Pole to be used exploited much more than ever before.

It is difficult to make projections about the future of the National Stadium in Bratislava, but it certainly gives hope for better times for Slovak sports. The stadium cannot be expanded and its capacity cannot be increased. If such a need arises, in the case of a long-term increase in attendance rate, the construction of a new, even larger facility should be considered. From today's perspective, it seems to be quite a distant future. Slovan Bratislava has only managed to fill its stadium three times since moving to Tehelné Pole. Referring to these results should be a challenge for the club and a way to ensure its profits from the new facility. The observation of the phenomena taking place at the Bratislava stadium, as well as the stadiums of other Slovak cities where new sports facilities have been modernised or new ones have been built, is a source of data that can be used to explore the impact of sports infrastructure on the average spectator attendance at football matches. 


\section{ZNACZENIE STADIONU NARODOWEGO TEHELNÉ POLE DLA BRATYSŁAWY I ROZWOJU PIŁKI NOŻNEJ NA SŁOWACJI}

\section{WSTĘP}

We współczesnym świecie jest już niewiele takich miejsc gdzie ludzie nie pasjonują się piłką nożną (Sourav, 2020). Niemniej jednak takie odosobnione oazy istnieją, w których ta dyscyplina ustępuje miejsca innej, nie mniej popularnej. Według wskazań źródeł jednym z takich wyjątkowych miejsc jest Słowacja, w której nie piłka nożna ale hokej na lodzie jest najpopularniejszym sportem (Wood, 2015). Ten fenomen uzasadniają długie tradycje tej dyscypliny sportu w kraju i sukcesy odnoszone na poziomie reprezentacji narodowej oraz klubów hokejowych - klubowym (HC BULLS, 2020). Piłka nożna na Słowacji pod tym względami prezentuje się znacznie gorzej. Jednak łatwość uprawiania tej dyscypliny sportu, w porównaniu do wymagań hokeja oraz jej globalny wymiar sprawiają, że obecnie na Słowacji obie te dyscypliny można zestawiać niemalże na równi pod względem popularności.

Najbardziej znanym i utytułowanym klubem sportowym na Słowacji jest Slovan Bratysława. Po rozpadzie Czechosłowacji, drużyna ta dziewięciokrotnie zdobywała mistrzostwo kraju w piłce nożnej. Do tego wyniku może próbować równać jedynie MŠKK Żylina, która wygrała krajową ligę siedmiokrotnie. Najbardziej widocznym „hamulcem”, który od lat wstrzymywał rozwój Slovana był jego przestarzały stadion. Tehelné Pole, w dzielnicy Nové Mesto, od czasu otwarcia w 1941 roku stanowił „serce” strefy rekreacyjno-sportowej Bratysławy. Ten wielosekcyjny klub zasługuje na uznanie, gdyż posiada w swoich szeregach nie tylko drużynę piłkarską, ale również hokejową, rugby, koszykówki i wiele innych sekcji sportowych. Są one rozproszone w różnych miejscach w okolicy stadionu piłkarskiego, gdyż w tym obiekcie nie ma dla nich miejsca.

Pierwotny obiekt Tehelné Pole rozebrano w 2013 roku, po to by wybudować w jego miejsce nowy. Ten proces rozpoczęto po trzech latach, a uroczysta inauguracja nowego miała miejsce 3 marca 2019 roku. Stadion Narodowy w Bratysławie był jedynym z wielu obiektów sportowych postawiony w ostatnim dziesięcioleciu na Słowacji. W tym okresie wiele czołowych klubów w kraju przeprowadziło modernizacje swoich stadionów lub budowały je od podstaw - na nowo. Tego typu operacje wykonano m.in. w Popradzie (2014 rok), Trnawie (2015 rok), Dunajskiej Stredzie (2017 rok) i Nitrze (2018 rok). Kolejna w najbliższym czasie obejmie arenę piłkarską w Trenczynie.

Jedną z przyczyn budowy nowego stadionu w Bratysławie był fakt, że stare Tehelné Pole przestało spełniać wymogi międzynarodowych federacji piłkarskich w sprawie organizacji meczów kadry narodowej. Dla władz miasta był to swego rodzaju afront, który ostatecznie wymusił podjęcie decyzji o budowie nowego stadionu. Nowe Tehelné Pole projektu Karola Kallay'a (autora m.in. Słowackiego Pawilonu na EXPO 2015 w Mediolanie) od początku aspirowało do miana stadionu narodowego największej i najbardziej prestiżowej areny sportowej w kraju. W rozmowie architekci zdradzili, że $w$ tym celu od samego początku musieli projektować obiekt zgodnie z rygorystycznymi wytycznymi UEFA, z zamiarem uzyskania najwyższej czterogwiazdkowej oceny (Kallay ml., 2020). Dlatego też, wśród regulacji projektanci uwzględniali wszystkie wymogi standardów jakości zapewniające widzom, przedstawicielom mediów i sportowcom najwyższy komfort (UEFA, 2018). Ostatecznie obiekt pomyślnie przeszedł inspekcję UEFA i bez problemu uzyskał zakładany certyfikat jakości (TASR, 2020).

Żeby sprawdzić jakość tej inwestycji i poznać jej wpływ na rozwój Bratysławy, przykładowego dużego miasta regionu Europy Środkowej, autor dokonał próby kompleksowej oceny sposobu funkcjonowania wspomnianego stadionu oraz wyróżnienia elementów składowych wpływających na efektywność jego działania w zróżnicowanych skalach: regionu, miasta i dzielnicy. Pełną analizę studium przypadku uzupełniają badania wykonane metodami jakościowymi, takie jak porównania statystyczne, a także informacje uzyskane z wywiadów z ekspertami z dziedziny architektury obiektów sportowych.

Badania wykonywane za pomocą tych metod weryfikują plany i wyjaśniają koncepcje (użyte narzędzia projektowe i procesy zachodzące w przestrzeni) w odniesieniu do cech miejsca, rozpatrywanego w rożnych kontekstach: społecznym, kulturowym, historycznym, ekologicznym, ekonomicznym i bezpieczeństwa. 


\section{SKALA REGIONALNA}

Słowacja nigdy nie była potęgą europejskiego futbolu - dowodzą temu rankingi narodowych reprezentacji (ranking FIFA, stan z 22 października 2020 roku: 37. miejsce na świecie, 21. miejsce w Europie) i drużyn ligowych - ligowe (29. współczynnik UEFA). Kraj ten posiada jednak potencjał do pełnienia większej roli na rynku europejskim niż obecnie. Przykład Austrii i Czech wyraźne wskazuje, że nawet porównywalne pod względem liczby mieszkańców do Słowacji kraje mogą mieć silną reprezentację narodową i krajową ligę.

Jednym z czynników hamujących rozwój sportu w Słowacji jest ukształtowanie granicy tego kraju i nietypowe położenie jego stolicy - przylegającej do zachodniej granicy.

Fakt ten sprawia, że środek ciężkości względem gęstości zaludnienia kraju jest wyraźne odchylony w kierunku zachodnim. Na wschodzie kraju jest ona dużo mniejsza i kluby z tego obszaru pełnią marginalną rolę $w$ krajowej strukturze ligowej. W najwyższej klasie rozgrywkowej gra jedynie drużyna z Michalovca, a w niższej o szczebel klasie kluby z Koszyc, Bardejowa i Trebiszowa (Ryc. 1).

Koncentracja silnych klubów na zachodzie Słowacji powoduje, że Slovan Bratysława, pomimo tego, że jest najpopularniejszym klubem piłkarskim w kraju, ma ograniczone możliwości pozyskiwania kibiców z innych regionów. Dowodzi tego zestawienie pięciu miast posiadających kluby piłkarskie w najwyższej krajowej klasie rozgrywkowej w odległości do $100 \mathrm{~km}$ od Bratysławy: Senica $(25 \mathrm{~km})$, Dunajska Streda (45 km), Trnawa (48 km), Sered' (55 km) i Nitra (88 km).

Kolejnym czynnikiem, który na pewno nie ułatwia popularyzowania piłki nożnej w Bratysławie jest bliskość Wiednia. Liga austriacka stoi na znacznie wyższym poziomie niż słowacka, co zgodnie z opinią ekspertów z pewnością sprawia, że kibice przedkładający poziom rozgrywek piłkarskich ponad lokalny patriotyzm, decydują się na oglądanie austriackiej Bundesligi (Kuper and Szymański, 2017). Wiedeń reprezentują w tej lidze aż trzy drużyny: Austria, Rapid i Admira Wacker.

Tab. 1. Zestawienie średnich frekwencji, pojemności stadionów i liczby mieszkańców miast słowackich, posiadających kluby piłkarskie w najwyższej klasie rozgrywkowej w kraju (Fortuna Liga) w sezonie 2018/19. Żródło: opracowanie autora

\begin{tabular}{|l|r|r|r|}
\hline Miasto & L. mieszk. & Poj. stad. & Śr. frekw. \\
\hline Bratysława & 432.864 & 22.500 & 6.114 \\
\hline Żylina & 82.954 & 11.313 & 2.577 \\
\hline Nitra & 76.655 & 11.384 & 1.086 \\
\hline Trnawa & 63.924 & 19.200 & 3.700 \\
\hline Trenczyn & 55.333 & 4.300 & 564 \\
\hline Michalovce & 30.950 & 7.000 & 1.437 \\
\hline Ružomberok & 26.709 & 5.000 & 1.372 \\
\hline Dunajská Streda & 22.730 & 12.700 & 7.996 \\
\hline Senica & 20.324 & 5.070 & 906 \\
\hline Žiar nad Hronom & 19.083 & 2.309 & 1.546 \\
\hline Zlaté Moravce & 11.465 & 4.000 & 2.466 \\
\hline
\end{tabular}

Tab. 2. Zestawienie średnich frekwencji, pojemności stadionów i liczby mieszkańców miast polskich, posiadających kluby piłkarskie w najwyższej klasie rozgrywkowej w kraju (Ekstraklasa) w sezonie 2018/19. Żródło: opracowanie autora

\begin{tabular}{|l|r|r|r|}
\hline Miasto & L. mieszk. & Poj. stad. & Śr. frekw. \\
\hline Warszawa & 1.777 .972 & 30.967 & 18.672 \\
\hline Kraków & 771.069 & 48.146 & 25.166 \\
\hline
\end{tabular}




\begin{tabular}{|l|r|r|r|}
\hline Łódź & 685.285 & 5.700 & 5.295 \\
\hline Wrocław & 640.648 & 42.771 & 14.613 \\
\hline Poznań & 536.438 & 42.834 & 14.941 \\
\hline Gdańsk & 466.631 & 43.615 & 10.703 \\
\hline Szczecin & 402.465 & 18.027 & 3.699 \\
\hline Częstochowa & 222.292 & 5648 & 2.950 \\
\hline Kielce & 195.774 & 15.500 & 7.037 \\
\hline Gliwice & 179.806 & 10.037 & 4.494 \\
\hline Zabrze & 173.374 & 24.563 & 13.167 \\
\hline Płock & 120.000 & 10.978 & 4.522 \\
\hline Lubin & 72.581 & 16.086 & 4.116 \\
\hline
\end{tabular}

Tab. 3. Zestawienie średnich frekwencji, pojemności stadionów i liczby mieszkańców miast niemieckich, posiadających kluby piłkarskie w najwyższej klasie rozgrywkowej w kraju (Fortuna Liga) w sezonie 2018/19. Źródło: opracowanie autora

\begin{tabular}{|c|c|c|c|}
\hline Miasto & L. mieszk. & Poj. stad. & Śr. frekw. \\
\hline Berlin & 3.644 .826 & 96.661 & 71.147 \\
\hline Monachium & 1.471 .508 & 75.024 & 75.000 \\
\hline Kolonia & 1.085 .664 & 50.000 & 49.717 \\
\hline Frankfurt & 753.056 & 51.500 & 50.020 \\
\hline Dusseldorf & 619.294 & 54.600 & 41.324 \\
\hline Lipsk & 587.857 & 42.146 & 40.809 \\
\hline Dortmund & 587.010 & 81.365 & 81.171 \\
\hline Brema & 569.352 & 42.100 & 40.821 \\
\hline Augsburg & 295.135 & 30.660 & 28.710 \\
\hline Mönchengladbach & 261.454 & 54.022 & 51.103 \\
\hline Gelsenkirchen & 260.305 & 62.271 & 61.075 \\
\hline Fryburg & 230.241 & 24.000 & 23.925 \\
\hline Moguncja & 217.118 & 34.000 & 27.081 \\
\hline Leverkusen & 163.838 & 30.210 & 27.770 \\
\hline Paderborn & 150.580 & 15.000 & 14.434 \\
\hline Wolfsburg & 124.151 & 30.000 & 24.351 \\
\hline Hoffenheim & 35.442 & 30.150 & 26.741 \\
\hline
\end{tabular}

Celem uwidocznienia potencjału kibicowskiego i infrastruktury ligi słowackiej na tle innych krajów opracowano wykresy przedstawiające linie trendu dla pojemności stadionów (funkcja niebieska) i średnich frekwencji (funkcja pomarańczowa) względem liczby mieszkańców w danym mieście (oś X) dla trzech państw: Słowacji, Polski i Niemiec. Takie porównanie umożliwia odzwierciedlenie różnic infrastrukturalnych między Słowacją a dwoma państwami tego samego regionu (Europy Środkowej), 
z bardziej rozwiniętą infrastrukturą sportową i większym zainteresowaniem oglądania widowisk sportowych na żywo.

Z wykresów wynika, że poziom zapotrzebowania na infrastrukturę sportową na Słowacji (Ryc. 2) jest dużo niższy niż w Polsce (Ryc. 3) i Niemczech (Ryc. 4). Ta tendencja jest widoczna przy porównaniu kątów nachylenia obu funkcji. W przypadku Niemiec rosną one najszybciej. Ponadto ich linie odzwierciedlają realny popyt na oglądalność meczów piłkarskich na żywo w danym kraju. Stopień zainteresowania oglądalnością uwidacznia nałożenie na siebie obu tych funkcji. Z ich zestawienia wynika, że dla Słowacji ich początki niemalże się ze sobą stykają, a dalej Inie tych funkcji wyraźnie się od siebie oddalają (średnia frekwencja: 32\%). Natomiast funkcje z wykresem dla Polski są zbliżone do układu równoległego, jednakże są od siebie wyraźnie oddalone (średnia frekwencja: 45\%). Największy stopień podobieństwa funkcji wykazuje modelowy przykład Niemiec (średnia frekwencja: 92\%).

Średnia pojemność stadionu w tym kraju stanowi 16,2\% populacji miasta, w Polsce 7,5\%, natomiast na Słowacji aż $21,9 \%$. Z kolei średnia frekwencja względem populacji miasta wynosi w tych państwach $14,7 \%, 3,0 \%$ i 8,3\% (Tab. 1). Z tych danych wynika, że słowackie kluby posiadają za duże stadiony - zbyt duże rezerwy ich pojemności w stosunku do swoich potrzeb (Ryc. 2-4).

\section{SKALA MIASTA}

Dominacja Slovana Bratysława pod względem popularności jest jeszcze wyraźniejsza w skali miasta. Klub ten uważa się w stolicy za monopolistę, ponieważ jako jedyna drużyna w mieście, od sezonu 2010/11 występuje na najwyższym poziomie rozgrywkowym w kraju. To sprawia, że klub posiada największy potencjał kibicowski na Słowacji. Do sezonu 2009/10 w 1. lidze słowackiej występowała również FC Petržalka (obecnie 2. liga) wspierana finansowo przez znanego biznesmena Ivana Kmotrika. Był to okres dominacji tego klubu w lidze i największych sukcesów drużyny: zdobycie dwóch mistrzstwa kraju (sezon 2004/05 i 2007/08) i wywalczeniu awansu do fazy grupowej UEFA Champions League - najbardziej prestiżowego turnieju klubowego w piłce nożnej na świecie (sezon 2005/06). Gdy zabrakło sponsora skończyły się dobre czasy tej drużyny i zaczęły się problemy. Ze względu na kłopoty finansowe klub został zmuszony pozbyć się swoich najlepszych zawodników. Zdaniem Brody, był to ostateczny powód utraty miejsca w 1. lidze i do dziś do niej nie wrócił (Broda, 2019). Oprócz Petržalki, piłka nożna w stolicy kraju miała również innych godnych reprezentantów. Dziś po tych klubach postało niewiele śladów - zostały rozwiązane lub stanowią cień dawnej potęgi. Jednym z tego typu przykładów jest Inter Bratysława - dwukrotny mistrz Słowacji z sezonów 1999/00 i 2000/01, który obecnie gra na trzecim poziomie rozgrywkowym (Tab. 4).

Tab. 4. Zestawienie czynnie działających drużyn piłkarskich w Bratysławie w sezonie 2020/21, klasa rozgrywkowa, w której rozgrywają swoje mecze, rok założenia i odległość ich stadionu/boiska od Tehelnego Pola. Źródło: opracowanie autora

\begin{tabular}{|l|c|c|r|}
\hline Nazwa klubu & $\begin{array}{l}\text { Liga } \\
\mathbf{( 2 0 / 2 1 )}\end{array}$ & $\begin{array}{l}\text { Rok } \\
\text { zał. }\end{array}$ & $\begin{array}{l}\text { Odległość } \\
\text { do T.P. }[\mathbf{k m}]\end{array}$ \\
\hline Slovan Bratysława & 1 & 1919 & n.d. \\
\hline FC Petržalka & 2 & 1898 & 5,8 \\
\hline Inter Bratislava & 3 & 1940 & 1,4 \\
\hline Rača Bratislava & 3 & 1925 & 5,5 \\
\hline Lokomotíva Devínska Nová Ves & 3 & 1923 & 15,3 \\
\hline ŠK Vrakuňa Bratislava & 4 & 1939 & 6,4 \\
\hline FKM Karlova Ves Bratislava & 4 & n.d. & 7,1 \\
\hline SDM Domino & 4 & 1993 & 2,6 \\
\hline FK Vajnory & 4 & 1933 & 9,0 \\
\hline
\end{tabular}




\begin{tabular}{|l|c|c|r|}
\hline FK Lamač Bratislava & 4 & 1943 & 10,2 \\
\hline TJ Jarovce Bratislava & 5 & 1949 & 12,9 \\
\hline NŠK 1922 Bratislava & 5 & 1922 & 1,6 \\
\hline MŠK Iskra Petržalka & 5 & 1934 & 8,4 \\
\hline ŠK Krasňany Bratislava & 5 & n.d. & 4,9 \\
\hline MKF Slovan Záhorská Bystrica & 5 & n.d. & 14,6 \\
\hline FK The Dragons & 6 & 2011 & 0,9 \\
\hline Futbalová Komunita Kozmos & 6 & 2019 & 2,0 \\
\hline FTJ Slávia Ekonóm Bratislava & 6 & 1955 & 0,5 \\
\hline
\end{tabular}

Lokalizacja stadionu Tehelné Pole jest idealna pod względem dostępności dla mieszkańców miasta. Obręb działki znajduje się w centralnej części dzielnicy Novego Mesta - nowego centrum komercyjnego Bratysławy. W pobliżu stadionu przebiegają linie komunikacji miejskiej (200 m do najbliższego przystanku), które umożliwiają łatwy dostęp - przyjazd autobusem lub tramwajem pod stadion niemalże ze wszystkich części miasta. Ulokowane w niewielkiej odległości od stadionu przystanek kolejowy $(1,5 \mathrm{~km})$ i lotnisko $(5,3 \mathrm{~km})$ sprzyjają przyjezdnym z dalszych części kraju i kibicom zagranicznym (Ryc. 5).

\section{SKALA DZIELNICY}

Dzielnica Nové Mesto, w której znajduje się Tehelné Pole, była do XX wieku słabo zurbanizowanym terenem na północnych peryferiach Bratysławy. Pierwsze ważniejsze obiekty zaczęto na nim wznosić dopiero w latach dwudziestych XX wieku. Były to obiekty przemysłowe m.in.: browar oraz fabryki dynamitu i wyrobu czekolady. Rozwój dzielnicy zmienił swój kierunek po zajęciu, znajdującej się na południu miasta, Petržalki przez nazistowskie Niemcy (1938 rok) i ograniczeniu wstępu mieszkańcom na jej teren (Kováč, 2014). Wówczas znajdowały się tam najważniejsze obiekty i przestrzenie rekreacyjno-sportowe miasta. Według Fischera władze Bratysławy postanowiły zrekompensować ten niedostatek budując nowe areny sportowe w dzielnicy Nové Mesto (Fischer, 2020).

W jej obrębie sukcesywnie zaczęto wznosić kolejne obiekty sportowe: stadion lekkoatletyczny i piłkarski, tor żużlowy, stadion zimowy, pływalnię miejską, stadion rowerowy oraz korty tenisowe. Jako pierwszy powstał stadion piłkarski i lekkoatletyczny według projektu Kamila Grossa. Obiekt dla 25000 widzów, z 1750 miejscami siedzącymi, oddano do użytku 26 września 1940 roku. Po wojnie stopniowo zwiększano pojemność stadionu, osiągając maksymalną ilość miejsc dla 60000 kibiców. W latach 90-tych stadion przeszedł ostatnią modernizację, której efektem była m.in. redukcja pojemności obiektu do 30000 krzesełek. Stadion ostatecznie wyburzono w 2013 roku, a na jego miejscu zaprojektowano całkowicie nowy obiekt (Kováč, 2014).

Dziś kompleks rekreacyjno-sportowo-komercyjny stanowi nowoczesne centrum stolicy Słowacji, a powstały w 2019 roku, Stadion Narodowy Tehelné Pole jest uważany za jego "serce” (Ryc. 6). Wcześniej jego obecną rolę spełniały dwa stadiony: stare Tehelné Pole i Pasienky - były stadion Interu Bratysława. Obiekt ten nadal jest użytkowany przez Slovana Bratysława. Odbywają się na nim m.in. mecze drużyny rezerw tego klubu. Jego charakterystyczne wysokie słupy oświetleniowe nawet obecnie stanowią dominanty przestrzenne, dzięki którym lokalizacja stadionu jest łatwiejsza niż Tehelnego Pola. Ten, w przypadku braku wiedzy o jego położeniu, jest znacznie trudniejszy do zlokalizowania - dostrzeżenia. Wrażenie to pogłębiają kolejne wysokościowce budowane na terenie dzielnicy. Charakterystyczne Tri Veže, projektu Petera Moravčíka, zlokalizowane tuż przy Tehenym Polu stanowią najbardziej rozpoznawalny „drogowskaz” wskazujący drogę na stadion. 
W skład obecnego kompleksu rekreacyjno-sportowego wchodzą również: basen, korty tenisowe (2 zespoły), boiska piłkarskie, stadion do hokeja na lodzie, hala sportowa, Park Jama, Kuchajda (zalew) i hala widowiskowa. W omawianej strefie zagospodarowano również mniejsze przestrzenie rekreacyjne oraz obiekty sportowe, w których swoją działalność prowadzą kluby zrzeszające mniejsze grupy sportowej społeczności. Na terenie kompleksu znaleźć można również obiekty komercyjne m.in.: Kaufland i centrum handlowe Polus. Funkcje te sprawiają, że kibice mogą przed lub po wydarzeniu masowym udać się na zakupy, wydłużając swój pobyt w dzielnicy. Temu działaniu sprzyja również obecność ważnych arterii komunikacyjnych znajdujących się wokół tego terenu. Łączą one dzielnicę z resztą miasta i drogami wylotowymi, polepszając dostępność strefy. Tym samym traci przez to swoje walory użytkowe dla ruchu pieszego - względem kibiców poruszających się piechotą. Sprawcą tego niskiego notowania jest intensywny ruch samochodowy, który stwarza ryzyko wypadków.

\section{SKALA STADIONU}

Stadion Tehelné Pole, oddany do użytku w lutym 2019 roku, miał swoje oficjalne otwarcie w dniu prestiżowego meczu Slovan Bratysława - Spartak Trnava 3 marca 2019 roku. W tym dniu po raz pierwszy elewacja stadionu, złożona z iluminowanych membran, zmieniła swój kolor na barwy klubu (niebieskie) (Ryc. 7). Efekty podświetlenia wykorzystuje się również podczas meczów reprezentacji narodowej. Zgodnie z wiedzą Kallay'a kolor elewacji mieni się w tym czasie barwami słowackiej flagi (Kallay ml., 2020).

Jednym z charakterystycznych elementów, wyróżniających Tehelné Pole wśród innych współczesnych stadionów, jest wbudowany w narożu areny budynek biurowy. Zgodnie z teorią Zinganela, zabieg ten był konieczny ze względu na wytyczne włodarzy miasta, którzy w trosce o finansowy sukces inwestycji zabiegali o zróżnicowanie znajdujących się w niej funkcji (Zinganel, 2010). Ponadto plan zagospodarowania terenu zakładał budowę od strony ul. Bajkalskà wielorodzinnych budynków mieszkalnych. Takie założenia sprawiły, że obiekty te należało wkomponować w strukturę stadionu. Budynek mieszkalny, pomimo ukończenia, nadal nie jest w całości zamieszkały. Dotyczy to również przestrzeni usługowych, ulokowanych w parterze obiektu. Ich rozmieszczenie wymaga odpowiedniego dostosowania, w taki sposób żeby możliwe było pogodzenie codziennej obsługi klientów (spoza dni meczowych) z obsługą kibiców podczas dni meczowych i innych imprez masowych. W takich dniach ilość i asortyment ich potrzeb (robionych zakupów) stawia duże wymagania sprzedawcom i zdaniem ekspertów nie zawsze udaje się im sprostać (Usydus, 2020)(Usydus, 2020)(Usydus, 2020).

Wokół stadionu zaprojektowano kilka przestrzeni publicznych, sprzyjających integracji mieszkańców i kibiców Obecnie ze względu na zagrożenie epidemiczne COVID-19 są one niemalże całkowicie wyludnione i w niczym nie przypominają żyjących przestrzeni wokół aren sportowych. Na Tehelnym Polu, wyróżniają się przestrzenie przed wejściem na stadion w postaci wyniesionego, o sześć metrów ponad poziom ulicy, tarasu okalającego obiekt. Prowadzą do niego rampy i schody, które spełniają jednocześnie funkcję kontroli bezpieczeństwa. Projektanci uwzględnili potrzeby osób starszych i niepełnosprawnych, dla których wszelkiego rodzaju rampy i schody stanowią duże utrudnienie i umieścili dla nich specjalne windy wewnątrz struktury stadionu.

Podwyższenie zaprojektowano w formie galerii, która umożliwia obchodzenie obiektu i dojście do właściwej strefy, widniejącej na zakupionym bilecie wstępu. Większość przestrzeni została dostosowana do masowego przemieszczania się, ale wydaje się, że część z nich jest zbyt wąska i nie może spełniać tego warunku. Teoretycznie nie powinno być kłopotów w przypadku ewakuacji, gdyż według przeprowadzonych symulacji opróżnienie stadionu, w sytuacji zagrożenia, zajmuje łącznie sześć minut (Kallay ml., 2020). Na poprawę stanu bezpieczeństwa w obiekcie ma duży wpływ rozmieszczenie nagłośnienia. Jest ono równomiernie rozmieszczone, wewnątrz, jak również na zewnątrz obiektu. Zabieg ten sprawia, że niezależnie od miejsca pobytu kibiców, komunikaty powinny być doskonale słyszalne. 
Bilety wstępu na imprezy sportowe można dokonywać w dwóch stacjonarnych punktach, znajdujących się po przeciwległych stronach stadionu oraz online - drogą elektroniczną. Po okazaniu wejściówki każdy kibic jest fotografowany. Władze klubu zapewniają, że utrwalone wizerunku uczestników stanowią ważny element systemu bezpieczeństwa (ŠK Slovan Bratislava, 2019). Wśród stałych zabezpieczeń zwraca uwagę ażurowa siatka okalająca arenę, przez którą jest dobry wgląd do jej wnętrza i na to co dzieje się wewnątrz obiektu. Zarządcy stadionu chwalą również nowatorski sposób dokonywania bezgotówkowych zakupów na terenie stadionu. Eisele twierdzi, że kibice/widzowie na czas trwania imprezy masowej mogą nabyć talony a później wymieniać je na produkty (żywność i napoje, pamiątki) oferowane podczas jej trwania (Eisele, 2020).

Pod obiektem zaprojektowano specjalne podziemne strefy parkingowe, przyporządkowane do obsługi każdej z funkcji struktury stadionu. Po zaparkowaniu samochodu, dostęp pieszy do każdego obiektu umożliwiają windy. Wyjazd z parkingu podziemnego ułatwiono poprzez zastosowanie ramp wyjazdowych wychodzących bezpośrednio na główną ulicę. Dzięki temu rozwiązaniu wokół obiektu nie trzeba było rozmieszczać wielkopowierzchniowych przestrzeni parkingowych dla samochodów osobowych i autokarów. Kierowcy, którzy z różnych powodów, nie chcą wjeżdżać do podziemnego parkingu mogą pozostawić auta na parkingach ulicznych, sąsiadujących ze stadionem ulic.

Kwestią dyskusyjną jest pojemność obiektu Tehelnego Pola. Wcześniej w artykule poruszono już ten problem, wskazując na przeszacowane pojemności stadionów na Słowacji. Biorąc pod uwagę klub Slovan Bratysława który do czasu wybudowania nowego stadionu notował średnie frekwencje w okolicach średniej ligowej, oznacza, że dla miasta posiadającego ponad pięciokrotnie więcej mieszkańców niż kolejna co do wielkości Žilina, jest wynikiem słabym. Notowane frekwencje dowodzą, że ich wartość od sezonu 2012/13 jest nawet mniejsza niż średnia krajowa (Ryc. 8). Gdyby przyjąć niemiecki współczynnik z zestawienia linii trendów średniej pojemności stadionów w tym kraju (Ryc. 2), Bratysława powinna zamiast stadionu o pojemności 22.500 miejsc wybudować arenę dla 50.000 widowni i zapełniać ją (uśrednioną liczbą) 45.000 osobami. W przypadku polskiego współczynnika (Ryc. 3) liczby te wynosiłyby odpowiednio 26.000 miejsc przy średnim zapełnieniu 11.200. Tyle wynika z teoretycznych rozważań, w rzeczywistości przeprowadzka Slovana Bratysława na nowe Tehelné Pole przyniosła odczuwalny wzrost średniej frekwencji z poziomu 3.382 do 6.114. Te wartości liczbowe w zestawieniu z (porównywalnymi wielkością do Bratysławy miastami) Gdańskiem i Bremą/Augsburgiem (Tab. 1-3) znacznie odbiegają od normy. Ich przyrost o $81 \%$ jest wyższy od podawanych przez Kościółka wartości (72\%), dla tzw. „Efektu nowego stadionu” (Kościółek, 2014), ale nie imponujący (jest przeciętny) w porównaniu z innymi klubami zlokalizowanymi w stolicach państw regionu Europy Środkowej (Ryc. 9)

Deficyt frekwencyjny na słowackich stadionach pogłębiły restrykcyjne przepisy (obostrzenia) związane z pandemią COVID-19. Władze kraju ostrożnie ograniczały liczbę kibiców przebywających na stadionach w czasie meczów ligowych. Właściciele obiektów musieli dodatkowo zadbać o bezpieczeństwo fanów i przystosować stadiony do wymogów sanitarnych. Spełnienie tych warunków polegało na oznaczeniu możliwych do zajęcia miejsc oraz rozlokowaniu wokół obiektu urządzenia z płynem do dezynfekcji rąk. Wraz z rosnącą liczbą dziennych zachorowań, 1 listopada 2020 roku podjęto decyzję o całkowitym zamknięciu stadionów dla kibiców. Od tego czasu mecze piłkarskie odbywały się bez udziału publiczności, podobnie jak w większości krajów Europy. Przepis ten zmieniono z początkiem sezonu 2021/22. Kibice słowackich drużyn mogą od lipca 2021 roku zapełniać stadiony na czas trwania meczów piłkarskiej w maksymalnie $50 \%$ ich pojemności. Pomimo tego dotychczasowe wyniki frekwencyjne (stan z 18 sierpnia 2021 roku) nie wskazują na to, żeby którykolwiek klub zbliżył się do tej granicy.

\section{PODSUMOWANIE}

Wykonane badania bezspornie ukazują nieporównywalnie wysoki potencjał rozwoju infrastruktury sportowej w Bratysławie w stosunku do pozostałych miast Słowacji. Nie można jednak twierdzić, że inwestycje $w$ tej dziedzinie, w tym mieście, powinny być wzorcem i inspiracją dla nowo planowanych obiektów sportowych w kraju. Przykład zmiany lokalizacji Stadionu Narodowego Tehelné Pole wska- 
zuje, że była to kluczowa decyzja, która zapoczątkowała rozwój miasta w kierunku północnym w kolejnych dziesięcioleciach. Stadion, wraz z sukcesywnie rozwijaną infrastrukturą rekreacyjno-sportową wokół niego, stanowił główny czynnik, dla którego w dzielnicy tej zaczęto budować kolejne nowoczesne budynki o zróżnicowanych funkcjach (usługowych, mieszkaniowych) wraz z infrastrukturą wspomagającą. Z biegiem czasu wszystkie te działania zaczęły stopniowo podnosić rangę dzielnicy, a wciąż powstające nowe zabudowania są dowodem, że trend ten w kolejnych latach będzie nadal postępował.

Otwarcie Tehelnego Pola miało nie tylko przyspieszyć rozwój dzielnicy Nové Mesto, ale także rozpocząć nowy rozdział w historii Slovana Bratysława i słowackiej piłki nożnej. Decyzja o zamknięciu stadionów dla słowackich kibiców, zatrzymała jednak na bliżej nieokreślony czas dobrze zapowiadający się rozwój klubu. Uważa się, że wraz z powrotem normalnych warunków rozgrywania meczów, Slovan Bratysława powinien szybko poprawić swoje wyniki finansowe. Eksperci są zgodni, że zmiana obiektu z monofunkcyjnego na wielofunkcyjny, poprzez rozszerzenie jego funkcji, przyniesie efekty i spowoduje, że inwestycja będzie na siebie zarabiać niezależnie od organizacji meczów piłkarskich (Palvarini and Tosi, 2013). Duża ilość przestrzeni usługowych, sal wielofunkcyjnych wewnątrz obiektu, ale przede wszystkim możliwość goszczenia na centralnej płycie boiska innych wydarzeń masowych sprawi, że Tehelné Pole będzie eksploatowane w dużo większym wymiarze niż kiedykolwiek wcześniej.

Trudno szacować jaka przyszłość czeka Stadion Narodowy w Bratysławie, ale z pewnością daje ona nadzieję na lepsze czasy dla słowackiego sportu. Stadion nie ma możliwości rozbudowy i powiększenia swojej pojemności. Gdyby jednak zaszła taka potrzeba w przypadku długotrwałego wzrostu frekwencji pozostaje rozważenie budowy nowego, jeszcze większego obiektu. Z dzisiejszej perspektywy wydaje się, że jest to dość odległa przyszłość. Slovanowi Bratysława od czasu przeprowadzki na Tehelné Pole udało się zapełnić swój stadion tylko trzy razy. Nawiązywanie do tych wyników to duże wyzwanie dla klubu - droga do zapewnienia mu profitów z nowego obiektu. Obserwacja zjawisk zachodzących na bratysławskim stadionie, jak również stadionach innych słowackich miastach, w których zmodernizowano lub zbudowano nowe obiekty sportowe, stanowi źródło danych do prób wyjaśniania wpływu infrastruktury sportowej na średnie frekwencje widzów na meczach piłkarskich.

\section{BIBLIOGRAPHY}

Broda, J. (2019) Artmedia Petrzalka - od zera do bohatera i z powrotem. Available at: https://igol.pl/artmediapetrzalka-od-zera-do-bohatera-i-z-powrotem/ (Accessed: 7 November 2020).

Eisele, Š. (2020) Tehelné pole ODHALENÉ! Pýcha Slovenska? Available at: https://www.youtube.com/watch?v=gOaQCRQc43E (Accessed: 7 November 2020).

Fischer, D. (2020) 'Personal interview'.

HC BULLS (2020) Vznik a história l'adového hokeja na Slovensku. Available at: https://hcbulls.sk/vznik-ahistoria-ladoveho-hokeja-na-slovensku/.

Kallay ml., K. (2020) 'Personal interview'.

Kościółek, S. (2014) 'Efekt nowego stadionu w polskiej Ekstraklasie piłkarskiej w latach 2007-2014', in Nessel, K. and Wszendybył-Skulska, E. (eds) Młodzi o sporcie 2014. Organizacja i marketing imprez sportowych. Cracow: Katedra Zarządzania w Turystyce Uniwersytetu Jagiellońskiego, pp. 99-116.

Kováč, B. (2014) 'Príbeh Tehelného Pol'a', Urbanita, 3, pp. 30-33. Available at: https://www.mindop.sk/uploads/SBPMR/Mestský rozvoj/URBANITA/URBANITA 3 2014.pdf.

Kuper, S. and Szymański, S. (2017) Futbonomia. Kraków: Sine Qua Non.

Palvarini, P. and Tosi, S. (2013) 'Globalisation, stadiums and the consumerist city: The case of the new Juventus stadium in Turin', European Journal for Sport and Society, 10(2), pp. 161-180. doi: 10.1080/16138171.2013.11687917.

ŠK Slovan Bratislava (2019) Vstup cez turnikety na Tehelné pole. Available at: https://www.youtube.com/watch?v=zkLQTDguDWI (Accessed: 7 November 2020).

Sourav (2020) Top 10 Most Popular Sports in The World. Available at: https://sportsshow.net/top-10-most- 
popular-sports-in-the-world (Accessed: 7 November 2020).

TASR (2020) 'Národný futbalový štadión je oficiálne uznaný: Tehelné pole dostalo významný certifikát'. Available at: www.sportky.zoznam.sk/c/225161/narodny-futbalovy-stadion-je-oficialne-uznany-tehelnepole-dostalo-vyznamny-certifikat.

UEFA (2018) 'UEFA Stadium Infrastructure Regulations Edition 2018'. Available at: uefa.com/MultimediaFiles/Download/uefaorg/Stadium\&Security/01/48/48/85/1484885_DOWNLOAD.pdf.

Usydus, S. (2020) 'Compostion of football stadiums and their surroundings', space \& FORM. Szczecin: Wydawnictwo Uczelniane ZUT, 42. doi: 10.21005/pif.2020.42.C-06.

Wood, R. (2015) Sport in Slovakia. Available at: https://www.topendsports.com/world/countries/slovakia.htm (Accessed: 7 November 2020).

Zinganel, M. (2010) 'The stadium as cash machine', Stadium Worlds: Football, Space and the Built Environment, pp. 77-97. doi: 10.4324/9780203848562.

\section{AUTHOR'S NOTE}

Szymon Usydus, architect and urban designer, PhD student at the City Rebuilding Laboratory, Faculty of Architecture, Cracow University of Technology. Scientific interests: urban and social issues related to public spaces in cities, architecture of stadiums, mobility and modularity in architecture and urban design.

\section{O AUTORZE}

Szymon Usydus, architekt, urbanista, doktorant w Zakładzie Odnowy Miast Wydziału Architektury Politechniki Krakowskiej. Zainteresowania naukowe: zagadnienia urbanistyczne i społeczne dotyczące przestrzeni publicznych miast, architektura stadionów, mobilność i modułowość w projektowaniu architektonicznym i urbanistycznym.

Contact | Kontakt: sz.usydus@gmail.com 